\title{
PELINDUNGAN PATEN DALAM PERSPEKTIF FUNGSI HUKUM SEBAGAI KONTROL SOSIAL DAN REKAYASA SOSIAL
}

\author{
Sudjana \\ Fakultas Hukum, Universitas Padjadjaran \\ sdjana@yahoo.com
}

Submitted: 2021-06-29 | Reviewed: 2021-08-29 | Accepted: 2021-11-08

\begin{abstract}
How to cite: Sudjana. "Perlindungan Paten Dalam Perspektif Fungsi Hukum Sebagai Kontrol Sosial dan Rekayasa Sosial”. Dialogia Iuridica: Jurnal Hukum Bisnis dan Investasi, Vol. 13, No. 1, (2021), 061-078.
\end{abstract}

DOI:

https://doi.org/10.28932/di.v13i1.3757

\section{ABSTRACT}

Law is a means of social control to direct people to take actions in accordance with applicable regulations so as to create order and peace. While the function of law as social engineering is to change human behavior in order to uphold justice and respect obligations under the law. This study aims to determine the function of law as social control and social engineering related to patent protection. The research method used is a socio-juridical approach that is descriptive-analytical. Data collection was carried out through literature study while data analysis was carried out in a qualitative normative manner. The results of the study show that the legal function as social control related to patents is the object, terms and procedures of protection and the period of protection, while the subject of protection and legal action in the event of a violation is the function of law as social engineering. However, in order to understand the requirements for granting patents and to eliminate the impression that patent registration is too procedural and to increase legal awareness in order to respect patents by other parties, it is necessary to continuously disseminate information or information through print or electronic media with the use of technological 
means which are currently developing rapidly so that can support the effectiveness of social control and social engineering as mandated by the Patent Law.

Keywords: $G$ Paten, Social Control, Social Engineering

\section{PENDAHULUAN}

Hukum dapat diartikan sebagai kaidah untuk mengatur kehidupan manusia dalam masyarakat agar tercipta kehidupan yang tertib, sehingga keberadaan hukum sebagai pengatur dan pedoman dalam interaksi sosial merupakan condition sine qua non dengan kondisi masyarakat yang tentram, serasi dan damai. Dengan demikian hukum memegang peranan penting dalam pergaulan manusia dalam masyarakat untuk menciptakan keadilan, kepastian hukum dan kemanfaatan.

Keadilan, kepastian hukum dan kemanfaatkan merupakan tujuan hukum konvensional dalam arti untuk menciptakan kondisi masyarakat yang harmonis, ketiga aspek tersebut mutlak diperlukan. Dalam kaitan dengan interaksi antar individu dengan individu, individu dengan kelompok dan kelompok dengan kelompok, norma hukum mengatur agar kepentingan masing-masing individu tidak bertentangan dengan kepentingan kelompok (umum) sehingga hak dan kewajiban individu dan masyarakat dalam suatu hubungan hukum berjalan dengan semestinya. ${ }^{1}$ Namun sejalan dengan perubahan sosial, yaitu perubahan nilai sikap prilaku termasuk pola berpikir diantara kelompok masyarakat, maka pandangan terhadap tujuan hukum (konvensional) juga berubah. Pada saat ini, hukum tidak hanya bertujuan untuk mencapai keadilan, kepastian hukum, dan kemanfaatan, tetapi hukum modern adalah dapat menjadi sarana perubahan sosial, baik sebagai kontrol sosial (social control) maupun sebagai rekayasa sosial (social engineering).

Hubungan antara perubahan sosial dan sektor hukum tersebut merupakan hubungan interaksi, dalam arti terdapat pengaruh perubahan sosial terhadap perubahan sektor hukum sementara di lain pihak perubahan hukum juga berpengaruh terhadap suatu perubahan sosial. Perubahan hukum yang dapat mempengaruhi perubahan sosial sejalan dengan salah satu fungsi hukum, yakni fungsi hukum sebagai sarana perubahan sosial atau sarana rekayasa masyarakat (social engineering). Hukum juga dapat menjadi alat kontrol sosial, yakni mengawasi perilaku masyarakat, karena itu lembaga-lembaga hukum dengan sendirinya juga merupakan lembaga (agency) kontrol sosial.

Hukum sebagai sarana rekayasa sosial (a tool of social engineering) perlu diberdayakan agar dapat mewujudkan supremasi hukum dalam berkehidupan berbangsa, bernegara dan bermasyarakat. Dalam kaitan ini terdapat perbedaan pandangan antara

\footnotetext{
${ }^{1}$ Muhammad Daud Ali, Hukum Islam Pengantar Ilmu Hukum dan Tata Hukum Islam di Indonesia, Jakarta: Raja Grafindo Persada, 2011, hlm 43.
} 
aliran sociological jurisprudence yang bertitik tolak pada living law (das sein) dan aliran hukum positif yang berpendapat bahwa hukum bertujuan menjamin adanya kepastian, sehingga melihat hukum sebagai das sollen (seharusnya) ${ }^{2}$. Namun, dalam melakukan pendekatan terhadap fungsi hukum, kedua aliran tersebut harus dipandang sebagai satu kesatuan yang utuh dan saling melengkapi.

Fungsi hukum sebagai kontrol sosial diartikan sebagai pengawas oleh masyarakat terhadap pemerintahan, sehingga kontrol sosial bertujuan mencapai keserasian antara stabilitas, dengan perubahan dalam masyarakat. ${ }^{3}$ Dari sudut sifatnya kontrol sosial bersifat preventif atau represif, preventif merupakan usaha pencegahan terhadap terjadinya gangguan kepastian keadilan, dan kemanfaatan. Sedangkan usaha represif bertujuan mengembalian keserasian hukum dengan masyarakat, proses kontrol sosial dapat dilaksanakan tanpa kekerasan (persuasif) ataupun paksaan (coercive).

Dalam perspektif negara hukum, tujuan utamanya adalah menyelenggarakan ketertiban, karena itu hukum merupakan sarana kontrol sosial yang diwujudkan melalui sanksi-sanksinya. Hal ini berarti bahwa hukum mengarahkan agar masyarakat berbuat secara benar menurut aturan sehingga ketentraman terwujud, Sedangkan fungsi hukum sebagai rekayasa sosial untuk mengubah prilaku agar berlaku adil dalam menghormati kewajiban menurut hukum yaitu tidak mengambil hak orang lain tanpa adanya legitimasi.

Isu hukum yang sekarang sedang berkembang adalah hukum kekayaan intelektual, yaitu hukum yang mengatur tentang pelindungan terhadap hasil kegiatan kreatif suatu kemampuan daya pikir manusia di bidang ilmu pengetahuan, seni, dan teknologi yang diekspresikan kepada khalayak umum dalam berbagai bentuknya, yang memiliki manfaat ekonomi serta berguna dalam menunjang kehidupan manusia. Salah satu bidang kekayaan Intelektual adalah paten yaitu hak atas kreasi yang diberikan oleh negara kepada inventor atas hasil invensinya di bidang teknologi baik produk maupun proses yang mempunyai peranan strategis dalam mendukung pembangunan bangsa dan memajukan kesejahteraan umum sesuai Pembukaan Undang-Undang Dasar Negara Republik Indonensia 1945 Alinea IV. Secara filosofis, pemberian hak paten oleh Negara memiliki tujuan untuk mendorong setiap individu menghasilkan kreasi yang bermanfaat bagi diri sendiri dan bangsa, sehingga pelindungan paten berkaitan erat dengan kebijakan pemerintah untuk melakukan perubahan sosial, yaitu perubahan sikap dan perilaku baik berfungsi sebagai kontrol sosial maupun rekayasa sosial melalui hukum paten. Dengan demikian, tujuan kajian ini adalah untuk menentukan pemberian paten dapat berfungsi sebagai kontrol sosial maupun rekayasa sosial, sehingga alasan pentingnya pelindungan paten berdasarkan Undang-Undang Nomor 13 Tahun 2016 tentang Paten (selanjutnya disebut UU Paten) yaitu peningkatan pelindungan paten sangat penting bagi inventor dan pemegang paten karena dapat memotivasi inventor untuk meningkatkan hasil karya, baik

\footnotetext{
2 Wibowo T. Tunardy, "Sociological Jurisprudence", https://www.jurnalhukum.com/sociologicaljurisprudence/ diakses pada tanggal 23 September 2021 pukul 21.00 WIB.

3 Dewi Iriani, "Hukum Sebagai Alat Kontrol Sosial dan Sistem Supremasi Penegakan Hukum", http://repository.iainponorogo.ac.id/256/1/sebagai\%20kontrol.pdf, diakses pada tanggal 23 Oktober 2021 pukul 20.00 WIB.
} 
secara kuantitas maupun kualitas untuk mendorong kesejahteraan bangsa dan negara serta menciptakan iklim usaha yang sehat sebagaimana asar Pertimbangan huruf c UndangUndang Nomor 13 Tahun 2021 tentang Paten. dapat diimplentasikan dengan baik.

Artikel tentang pelindungan paten yang sudah ada adalah tulisan Winner Sitorus," Kepentingan Umum Dalam Pelindungan Paten”, Jurnal Yuridika, Volume 29 No 1, Januari - April 2014. Novianti, Pelindungan Paten Melalui Patent Cooperation Treaty dan Regulations Under The Patent Cooperation Treaty, Jurnal Negara Hukum, Vol. 8, No. 2, November 2017, dan Jabalnur, Pelindungan Hak Paten Bagi Pengrajin Khas, Jurnal Holrev, Volume 1 Issue 2, September 2017. Ketiga artikel tersebut membahas pelindungan paten tetapi rumusan permasalahan berbeda dengan artikel ini. Kajian dalam artikel ini membahas masalah "bagaimana penerapan fungsi hukum sebagai kontrol sosial dan rekayasa sosial berkaitan dengan pelindungan paten". Kajian ini bertujuan untuk menentukan penerapan fungsi hukum sebagai kontrol sosial dan rekayasa sosial berkaitan dengan pelindungan paten, sehingga diharapkan dapat bermanfaat secara akademik untuk pengembangan ilmu pengetahuan khususnya hukum paten maupun praktis sebagai sumbangan pemikiran bagi pemangku kepentingan berkaitan dengan pelindungan paten sebagai kontrol sosial dan rekayasa sosial.

Metode penelitian yang digunakan bersifat deskriptif analisis yaitu mendeskripsikan secara utuh, terperinci, jelas, dan sistematis ${ }^{4}$ mengenai perlindungan paten dihubungkan fungsi hukum sebagai kontrol sosial dan rekayasa sosial sehingga merupakan pendekatan socio yuridis ${ }^{5}$ Pengumpulan data dilakukan melalui studi kepustakaan (library reseach) dengan mengkaji bahan hukum primer (UU Paten), bahan hukum sekunder (pendapat para ahli), dan bahan hukum tersier (kamus, ensiklopedia, internet dsb) serta kajian teori tentang fungsi hukum kemudian dianalisis secara kualitatif berdasarkan prinsip hukum, penafsiran, atau konstruksi hukum ${ }^{6}$

\section{PEMBAHASAN}

Kata "perlindungan" dan "pelindungan" berasal dari kata dasar yang sama, yaitu "lindung". Namun, imbuhan dan proses penurunannya berbeda. Kata perlindungan diturunkan dari lindung berlindung pelindungan, sedangkan pelindungan diturunkan dari lindung melindungi pelindungan. Berdasarkan proses pengimbuhannya, dapat diketahui bahwa makna kata "perlindungan" berhubungan dengan kata kerja berlindung, sedangkan kata "pelindungan" berhubungan dengan kata melindungi. Jadi, perlindungan berarti 'tempat berlindung', sedangkan pelindungan berarti 'perihal melindungi'.

\footnotetext{
${ }^{4}$ Soerjono Soekanto dan Sri Mamudji, Penelitian Hukum Normatif: Suatu Tinjauan Singkat, Jakarta: PT. Raja Grafindo Persada, 2015, hlm 15. Lihat juga Hanim Mafulah, "Pengecualian Perjanjian Yang Berkaitan Paten Dan Lisensinya Dalam Pengawasan Persaingan Usaha", SIGn Jurnal Hukum, Vol. 1 No. 2, 2020, hlm 90.

${ }^{5}$ Peter Mahmud Marzuki, Penelitian Hukum, Jakarta: Kencana Prenada Media Group, 2010, hlm 93.

${ }^{6}$ Burhan Ashshofa, Metode Penelitian Hukum, Jakarta: Penerbit Reineka Cipta, 2016, hlm 124.

${ }^{7} \mathrm{http}$ ///badanbahasa.kemdikbud.go.id/lamanbahasa/content/apa-perbedaan-makna-pelindungan-danpelin- dungan diakses pada tanggal 15 Juni 2021 pukul 22 WIB.
} 
demikian, istilah yang lebih tepat untuk menggambarkan maksud dari kajian ini adalah "pelindungan".

Pelindungan hukum merupakan pelindungan terhadap harkat dan martabat serta pengakuan hak asasi manusia yang dimiliki oleh subjek hukum dalam negara hukum berdasarkan pada ketentuan hukum yang berlaku guna mencegah terjadinya kesewenangwenangan, sehingga hukum berfungsi sebagai pelindungan atas kepentingan manusia ${ }^{8}$ antara lain kepemilikan hak atau kekayaan intelektual.

Dalam kaitan ini, terdapat dua teori secara filsafati mengenai anggapan hukum bahwa kekayaan intelektual adalah suatu sistem kepemilikan (property). Teori tersebut dikemukakan oleh John Locke yang berpengaruh di negara penganut sistem hukum common law dan Hegel yang sangat berpengaruh pada negara-negara penganut sistem hukum civil law, bermula dari teori hukum alam yang bersumber pada moralitas tentang apa yang baik dan apa yang buruk. John Locke mengajarkan konsep kepemilikan kaitannya hak asasi manusia. Locke menyatakan bahwa pada awalnya tidak ada hukum positif yang mengatur masalah kepemilikan (status naturalis), namun kemudian status naturalis tidak dapat dipertahankan karena negara tidak memiliki hakim yang dapat memberikan terjemahan terhadap pertentangan kepentingan antar individu. Status civilis adalah bentuk pengamanan bagi hak-hak alamiah yang tidak tersedia dalam status naturalis. Pada prinsipnya setiap orang tidak diperkenankan untuk merugikan orang lain, sehingga setiap individu memiliki hak alami (natural right) untuk memiliki buah atas jerih payahnya ${ }^{9}$

Karya intelektual dapat terwujud, bukan secara tiba-tiba namun melalui proses pemikiran, perenungan, uji coba, dan akhirnya membentuk hasil. Proses berkarya tersebut dimaknai oleh labor theory sebagai hak untuk menguasai invensi tersebut, sehingga orang lain dilarang mengakui invensi orang lain. Inventor telah bersusah payah untuk mewujudkan karya kekayaan intelektualnya, oleh karena itu patut diberikan kepadanya balas jasa atas karyanya. Hubungan timbal balik antara inventor dengan orang yang mengambil manfaat dari hasil karya, dalam teori pertukaran sosial (social exchange theory) sangat penting untuk dilakukan agar inventor termotivasi menghasilkan karya baru. ${ }^{10}$

Teori lain yang mendasari perlindungan hukum terhadap KI, yaitu: ${ }^{11}$

1. Teori Reward, bahwa pencipta di bidang ilmu pengetahuan, seni dan sastra, serta penemu di bidang teknologi baru yang mengandung langkah inovatif serta dapat

\footnotetext{
${ }^{8}$ Indi Fandaya, "Pertanggungjawaban Pemegang Lisensi-Wajib Menurut Undang-Undang Nomor 14 Tahun 2001 Tentang Paten”, USU Law Journal, Vol.5. No.3, 2017, hlm 12.

9 Rahmi Jened Parinduri Nasution, Interface Hukum Kekayaan Intelektual dan Hukum Persaingan (Penyalahgunaan HKI), Jakarta: Rajawali Press, 2013, hlm 26.

${ }^{10}$ Candra Irawan, Politik Hukum Hak Kekayaan Intelektual Indonesia: Kritik Terhadap WTO/TRIP's Agreement dan Upaya Membangun Hukum Kekayaan Intelektual Demi Kepentingan Nasional, Bandung: Mandar Maju, 2011, hlm 29. lihat juga Mieke Yustia Ayu Ratna Sari, "Pembangunan Kekayaan Intelektual (KI) Berbasis Teknologi Informasi Di Era Global", https://media.neliti.com/, diakses pada tanggal 19 Maret 2021 pukul 21.00 WIB.

${ }^{11}$ Ranti Fauza Mayana, Perlindungan Desain Industri di Indonesia dalam Era Perdagangan Bebas, Jakarta: Grasindo, 2004, hlm 89-90.
} 
diterapkan dalam industri, diberikan suatu penghargaan dan pengakuan serta perlindungan atas keberhasilan upayanya dalam melahirkan ciptaan baru itu;

2. Teori Recovery, bahwa atas usaha dari pencipta dan penemu yang telah mengeluarkan tenaga, pikiran, waktu dan biaya yang tidak sedikit jumlahnya, kepadanya diberikan hak eksklusif untuk mengeksploitasi KI guna meraih kembali yang telah dikeluarkannya;

3. Teori Incentive, bahwa insentif diberikan untuk merangsang kreativitas dan upaya menciptakan karya-karya baru di bidang teknologi;

4. Teori Public Benefit, bahwa KI merupakan suatu alat untuk meraih dan mengembangkan ekonomi.

Sistem pelindungan hukum kekayaan intelektual termasuk paten merupakan satu kesatuan tetapi dapat dibagi kedalam sub sistemnya yaitu subyek pelindungan, obyek pelindungan, syarat dan tatacara pelindungan, jangka waktu pelindungan, dan tindakan hukum yang dapat dilakukan apabila terjadi pelanggaran.

\section{Subyek Pelindungan Paten}

Subyek pelindungan paten adalah Inventor yaitu seorang atau beberapa orang yang secara bersama-sama melaksanakan ide yang dituangkan ke dalam kegiatan yang menghasilkan Invensi. Pasal 1 angka 3 UU Paten. Paten mengatakan "Inventor adalah seorang atau beberapa orang yang secara bersama-sama melaksanakan ide yang dituangkan ke dalam kegiatan yang menghasilkan Invensi”. Subjek Paten merupakan pemegang paten yaitu Inventor sebagai pemilik Paten, pihak yang menerima hak atas Paten tersebut dari pemilik Paten, atau pihak lain yang menerima lebih lanjut hak atas Paten tersebut yang terdaftar dalam daftar umum Paten. Inventor adalah seorang atau beberapa orang yang secara bersama-sama melaksanakan ide yang dituangkan ke dalam kegiatan yang menghasilkan Invensi. Sesuai dengan hal itu, Pasal 10 ayat (1) UU Paten, subyek paten adalah pihak yang berhak memperoleh Paten yaitu Inventor atau Orang yang menerima lebih lanjut hak Inventor yang bersangkutan. Pasal 10 ayat 2 UU Paten mengatakan "Jika Invensi dihasilkan oleh beberapa orang secara bersama-sama, hak atas Invensi dimiliki secara bersama-sama oleh para inventor yang bersangkutan", kecuali terbukti lain, pihak yang dianggap sebagai Inventor adalah seorang atau beberapa orang yang untuk pertama kali dinyatakan sebagai Inventor dalam Permohonan.

Pemegang Paten memiliki hak eksklusif untuk melaksanakan Paten yang dimilikinya dan untuk melarang pihak lain yang tanpa persetujuannya: a. dalam hal Patenproduk: membuat, menggunakan, menjual, mengimpor, menyewakan, menyerahkan, atau menyediakan untuk dijual atau disewakan atau diserahkan produk yang diberi Paten; $b$. dalam hal Paten-proses: menggunakan proses produksi yang diberi Paten untuk membuat barang atau tindakan lainnya. Larangan menggunakan proses produksi yang diberi Paten sebagaimana dimaksud huruf $b$, hanya berlaku terhadap impor produk yang semata-mata dihasilkan dari penggunaan proses yang diberi pelindungan Paten. Pemberian hak eksklusif sesuai dengan teori imbalan (reward theory) yang menjelaskan bahwa subyek 
paten yang perlu diberikan imbalan atas hasil jerih payahnya (waktu, biaya dan tenaga) dalam menghasilkan invensi yang bermanfaat bagi masyarakat. Namun, pemberian hak tersebut tidak absolut (mutlak), karena pelindungan paten harus memperhatikan keseimbangan dengan kepentingan umum, sehingga untuk kepentingan pendidikan, penelitian, percobaan, atau analisis, larangan tersebut dapat dikecualikan sepanjang tidak merugikan kepentingan yang wajar dari Pemegang Paten dan tidak bersifat komersial. Ketentuan ini dimaksudkan untuk memberikan kesempatan bagi pihak yang betul-betul memerlukan penggunaan Invensi semata-mata untuk penelitian dan pendidikan ${ }^{12}$ yang bukan bersifat komersial.

Pelindungan terhadap subyek paten berkaitan dengan kebijakan pemerintah untuk merekayasa individu atau kelompok individu (social engineering) melalui UU Paten, sehingga mendorong untuk berkreasi agar dapat menghasilkan invensi yang dapat meningkatkan taraf kesejahteraannya. Hal ini sesuai dengan pendapat Roscoe Pound yang mengatakan inti teorinya (social engineering) terletak pada konsep "kepentingan." Sistem hukum untuk mencapai tujuan ketertiban hukum dengan mengakui kepentingan tersebut, dengan menentukan batasan pengakuan atas kepentingan dan aturan hukum yang dikembangkan serta diterapkan oleh proses peradilan yang memiliki dampak positif serta dilaksanakan melalui prosedur yang berwibawa, juga berusaha menghormati berbagai kepentingan sesuai dengan batas-batas yang diakui dan ditetapkan. ${ }^{13}$ Pound mengatakan bahwa fungsi utama hukum adalah untuk melindungi kepentingan, yaitu kepentingan umum, kepentingan sosial, dan kepentingan pribadi, Pelindungan terhadap ketiga kepentingan tersebut harus dilakukan secara seimbang. Keseimbangan yang harmonis inilah yang merupakan hakikat dari keadilan. Atas dasar ini, secara garis besar Pound membuat tiga kategori kepentingan yaitu kepentingan individual (individual interests), kepentingan publik (public interests), dan kepentingan negara sebagai penjaga kepentingan masyarakat (interest of the state as a guardian of social interest). ${ }^{14}$ Kepentingan-kepentingan tersebut telah diakomodasi melalui UU Paten terkait dengan hak eksklusif (Pasal 19 ayat 1) untuk melindungi kepentingan individual; untuk melindungi kepentingan masyarakat sesuai Pasal 19 ayat 3 yaitu untuk kepentingan pendidikan, penelitian, percobaan, atau analisis, larangan penggunaan paten pihak lain dapat dikecualikan sepanjang tidak merugikan kepentingan yang wajar dari Pemegang Paten dan tidak bersifat komersial serta ketentuan tentang lisensi wajib (Pasal $81 \mathrm{~s} / \mathrm{d}$ Pasal 107) karena Paten telah dilaksanakan oleh Pemegang Paten atau penerima Lisensi dalam bentuk dan dengan cara yang merugikan kepentingan masyarakat; sedangkan untuk melindungi kepentingan Negara, ada ketentuan tentang Pelaksanaan Paten oleh Pemerintah berkaitan dengan pertahanan dan keamanan negara Pasal 109 s/d Pasal 120).

\footnotetext{
${ }^{12}$ Winner Sitorus, “Kepentingan Umum Dalam Pelindungan Paten”, Jurnal Yuridika, Vol. 29 No. 1, 2014, hlm 51.

${ }^{13}$ Munir Fuady, Teori-Teori Besar (Grand Theory) Dalam Hukum, Jakarta: Kencana Prennamdeia Group, 2013, hlm 35 .

${ }^{14}$ Atip Latipulhayat, "Khazanah: Roscoe Pound”, Padjadjaran Jurnal Ilmu Hukum, Vol. 1 No. 2, 2014, hlm 415 .
} 
Dialogia luridica: Jurnal Hukum Bisnis dan Investasi

Volume 13 Nomor 1, November 2021

\section{Obyek Pelindungan Paten}

Pasal 1 angka 1 UU Paten mengatakan "Paten adalah hak eksklusif yang diberikan oleh negara kepada inventor atas hasil invensinya di bidang teknologi untuk jangka waktu tertentu melaksanakan sendiri invensi tersebut atau memberikan persetujuan kepada pihak lain untuk melaksanakannya". Invensi adalah ide inventor yang dituangkan ke dalam suatu kegiatan pemecahan masalah yang spesifik di bidang teknologi berupa produk atau proses, atau penyempurnaan dan pengembangan produk atau proses.

Paten diberikan untuk Invensi yang baru, mengandung langkah inventif, dan dapat diterapkan dalam industri tetapi Invensi tidak mencakup sebagaimana tercantum dalam Pasal 4 UU Paten. Invensi dianggap baru jika pada Tanggal Penerimaan, Invensi tersebut tidak sama dengan teknologi yang diungkapkan sebelumnya (state of the art atau prior art). Teknologi yang diungkapkan sebelumnya merupakan teknologi yang telah diumumkan di Indonesia atau di luar Indonesia dalam suatu tulisan, uraian lisan atau melalui peragaan, penggunaan, atau dengan cara lain yang memungkinkan seorang ahli untuk melaksanakan Invensi tersebut sebelum Tanggal Penerimaan; atau tanggal prioritas dalam hal Permohonan diajukan dengan Hak Prioritas. Hak prioritas memberikan pelindungan bagi pemegang Paten, baik menurut hukum nasional (UU Paten) maupun hukum internasional yang tercantum dalam Konvensi Paris 1883 (Paris Convention for the Protection of Industrial Property) sebagai pendaftar pertama (first to file) untuk mendapatkan hak sebagai pemegang Paten. ${ }^{15}$

Paparan berikut ini merupakan prinsip penting terkait syarat kebaruan dari sebuah invensi yang akan diajukan permohonannya. ${ }^{16}$

a. Kriteria kebaruan mencakup menit, jam, dan hari;

b. Kabaruan didasarkan pada kriteria yang bersifat internasional;

c. Diketahui umum (publicly known) tidak terbatas pada jumlah orang yang mengetahuinya;

d. Invensi yang dapat dibaca oleh orang lain tidak harus selalu dalam bentuk publikasi. CD-ROM atau DVD-Room yang dapat dibaca oleh orang lain dapat dianggap sebagai publikasi.

Invensi mengandung langkah inventif jika Invensi tersebut bagi seseorang yang mempunyai keahlian tertentu di bidang teknik merupakan hal yang tidak dapat diduga sebelumnya. Untuk menentukan suatu Invensi merupakan hal yang tidak dapat diduga sebelumnya merupakan syarat yang paling subyektif karena pendapat ahli dapat berbeda, sehingga UU Paten mendasarkan pada kualitas invensi yaitu harus dilakukan dengan memperhatikan keahlian (pemeriksa paten) yang ada pada saat Permohonan diajukan. Di sisi lain, UU Paten tidak menjelaskan indikator atau contoh yang mengandung langkah

\footnotetext{
${ }^{15}$ Bandingkan dengan Yoyon M. Darusman, "Kedudukan Serta Perlindungan Hukum Bagi Pemegang Hak Paten Dalam Kerangka Hukum Nasional Indonesia Dan Hukum Internasional”, Yustisia, Vol. 5 No. 1, 2016, hlm 214.

${ }^{16}$ Tomi Suryo Utomo, Hak Kekayaan Intelektual (HKI) di Era Global, Yogyakarta: Graha Ilmu, 2010, hlm 118. lihat juga Japan Paten Office, (JPO), Industrial Property Rights-Standar, Textbook (General Information), Tokyo, JPO/JIII 2007, hlm 67.
} 
inventif. Untuk memahami hal tersebut, WIPO memberikan beberapa contoh invensi yang tidak mengandung langkah inventif, yaitu: ${ }^{17}$

a. Sebuah invensi yang semata-mata mengubah ukuran dari sebuah produk (mere change of size);

b. Sebuah invensi yang hanya sekedar membuat produk yang portable (making a product portable);

c. Sebuah invensi yang hanya memberikan pembalikan bagian (reveral of parts) dari invensi yang telah dikenal sebelumnya;

d. Sebuah invensi terkait perubahan bahan (the change of materials);

e. Sebuah invensi yang semata-mata merupakan penggantian sebuah benda yang mempunyai fungsi yang sama (the mere substitution by an equivakent part or function) dengan invensi lainnya.

Japan Paten office memberikan ukuran untuk menentukan sebuah invensi yang tidak mengandung langkah inventif, antara lain: ${ }^{18}$

a. Sebuah invensi yang semata-mata mengkombinasikan invensi yang telah dikenal dan digunakan (an invention merely combining known ans used invenstions);

b. Sebuah invensi yang semata-mata menggabungkan sebuah elemen dari sebuah invensi lain (an invention simply incorporating an element of another invention).

Invensi dapat diterapkan dalam industri jika Invensi tersebut dapat dilaksanakan dalam industri sebagaimana diuraikan dalam Permohonan. Invensi berupa produk yang dapat diterapkan dalam industri harus mampu dibuat secara berulang-ulang (secara massal) dengan kualitas yang sama, sedangkan jika Invensi berupa proses maka proses tersebut harus mampu dijalankan atau digunakan dalam praktek. Alasannya adalah invensi yang hanya dapat digunakan untuk tujuan akademis dan percobaan tidak dapat mencapai tujuan dari hakikat pemberian paten yang berfungsi untuk "mengembangkan industri." ${ }^{\prime 19}$ Contoh invensi yang dianggap tidak dapat dilaksanakan dalam industri adalah perawatan kesehatan berupa prosedur yang berhubungan dengan diagnosis atau pembedahan yang diterapkan terhadap manusia. ${ }^{20}$

Pelindungan terhadap obyek paten merupakan penerapan dari fungsi kontrol sosial karena pihak lain yang bukan inventor atau pemegang paten tidak dapat memiliki kualifikasi sebagai subyek paten sehingga dilarang menggunakan paten terdaftar kecuali dengan izin atau mekanisme lisensi atau hal-hal lain yang menurut UU Paten dapat dilakukan tanpa izin. Dari sisi obyek paten, untuk menentukan invensi yang dapat

\footnotetext{
${ }^{17}$ WIPO, Inventing the Future-An Introduction to Patens for Small and Medium-Sized Enterprises, Geneva, 2006, hlm 16.

${ }^{18}$ JPO op.cit, hlm 69.

19 JPO, ibid, hlm 66.

${ }^{20}$ Ibid.
} 
diberikan paten harus mengacu pada persyaratan yang telah ditentukan oleh UU Paten, sehingga setiap orang yang mengetahui bahwa terdapat paten yang sedang diajukan permohonan pendaftarannya tetapi tidak memenuhi syarat-syarat pemberian paten dapat mengajukan keberatannya.

\section{Syarat dan Tata Cara Pelindungan Paten}

Paten diberikan berdasarkan prinsip konstitutif yaitu pendaftaran yang diajukan oleh Pemohon atau Kuasanya kepada Menteri secara tertulis dalam bahasa Indonesia dengan membayar biaya. Setiap Permohonan diajukan untuk satu Invensi atau beberapa Invensi yang merupakan satu kesatuan Invensi yang saling berkaitan. Permohonan sebagaimana dimaksud dapat diajukan baik secara elektronik maupun nonelektronik.

Untuk memfasilitasi proses perolehan pelindungan paten di banyak Negara, maka pemohon dapat memanfaatkan fasilitas PCT (Patent Cooperation Treaty) yakni dengan hanya mengajukan satu permohonan pelindungan internasional paten melalui PCT, maka inventor Indonesia mendapatkan pelindungan hukum atas patennya di banyak negara dengan syarat negara tersebut harus menjadi anggota PCT dan Indonesia merupakan salah satu dari anggota PCT karena telah meratifikasi PCT berdasarkan Keputusan Presiden Nomor 16 Tahun 1997 tentang Pengesahan Patent Cooperation Treaty and Regulations under the PCT. ${ }^{21}$

Deskripsi tentang Invensi harus mengungkapkan secara jelas dan lengkap tentang bagaimana Invensi tersebut dapat dilaksanakan oleh orang yang ahli di bidangnya. Klaim atau beberapa klaim Invensi harus mengungkapkan secara jelas dan konsisten atas inti Invensi, dan didukung oleh deskripsi tersebut. Syarat dan tata cara pelindungan melalui pendaftaran berkaitan dengan fungsi hukum sebagai kontrol sosial, dalam arti invensi yang dihasilkan dapat dilindungi rezim hukum paten apabila memenuhi persyaratan dan tata cara pendaftaran tertentu sebagaimana tercantum dalam UU Paten. Berdasarkan pengawasan baik pemeriksaan baik adminitratif maupun substantif dapat ditentukan apakah invensi tersebut layak diberikan paten atau tidak.

\section{Jangka waktu Pelindungan Paten}

Paten diberikan untuk jangka waktu 20 (dua puluh) tahun untuk paten biasa dan 10 (sepuluh) tahun untuk paten sederhana terhitung sejak Tanggal Penerimaan dan tidak dapat diperpanjang. Tanggal mulai dan berakhirnya jangka waktu Paten dicatat dan diumumkan melalui media elektronik dan/atau media non-elektronik.

Jangka waktu pelindungan paten erat kaitan dengan fungsi kontrol sosial mengingat paten hanya mendapat pelindungan dalam jangka waktu tertentu sebagaimana ditetapkan oleh UU Paten, sehingga untuk kreasi teknologi yang sudah melampaui batas waktu pelindungan termasuk "public domain". Mekanime kontrol terhadap keberlakuan sebuah paten dapat dilihat dari sertifikat paten yang diterbitkan atau daftar umum paten yang disediakan oleh Direktorat Jenderal Kekayaan Intelektual.

\footnotetext{
${ }^{21}$ Novianti, "Pelindungan Paten Melalui Patent Cooperation Treaty dan Regulations UnderThe Patent Cooperation Treaty”, Jurnal Negara Hukum, Vol. 8 No. 2, 2017, hlm 291.
} 


\section{Tindakan hukum terhadap Pelanggaran Paten}

Pihak yang berhak memperoleh Paten dapat menggugat ke Pengadilan Niaga jika suatu Paten diberikan kepada pihak lain selain dari yang berhak memperoleh Paten. Hak menuntut secara perdata tidak mengurangi hak negara untuk menuntut secara pidana terhadap pelanggaran paten. ${ }^{22}$ Pemegang Paten atau penerima Lisensi berhak mengajukan gugatan ganti rugi kepada Pengadilan Niaga terhadap setiap Orang yang dengan sengaja dan tanpa hak melakukan perbuatan melanggar hak eksklusif. Gugatan ganti rugi yang diajukan terhadap perbuatan hanya dapat diterima jika produk atau proses itu terbukti dibuat dengan menggunakan Invensi yang telah diberi Paten.

Gugatan didaftarkan kepada Pengadilan Niaga dalam wilayah hukum tempat tinggal atau domisili tergugat sesuai dengan asas "Actor Sequitur Forum Rei," tetapi dalam hal salah satu pihak bertempat tinggal di luar wilayah Indonesia, gugatan didaftarkan kepada Pengadilan Niaga Jakarta Pusat. Dalam pemeriksaan gugatan terhadap proses yang diberi Paten, kewajiban pembuktian dibebankan kepada pihak tergugat jika: a. produk yang dihasilkan melalui proses yang diberi Paten dimaksud merupakan produk baru; atau b. produk diduga merupakan hasil dari proses yang diberi Paten, meskipun telah dilakukan upaya pembuktian yang cukup, Pemegang Paten tetap tidak dapat menentukan proses yang digunakan untuk menghasilkan produk dimaksud. Dengan demikian, pada dasarnya, kewajiban pembuktian menggunakan Asas Actori Incumbit Probatio, "barangsiapa yang mempunyai suatu hak atau menyangkal adanya hak orang lain, harus membuktikannya". Hal ini berarti bahwa dalam hal pembuktian yang diajukan penggugat dan tergugat sama-sama kuat, maka baik penggugat maupun tergugat ada kemungkinan dibebani dengan pembuktian oleh hakim. Terhadap putusan Pengadilan Niaga hanya dapat diajukan kasasi agar penyelesaian perkaranya menjadi lebih cepat, yang permohonannya didaftarkan kepada Pengadilan Niaga yang telah memutus gugatan dimaksud paling lama 14 (empat belas) hari sejak tanggal diucapkan atau diterimanya putusan yang dimohonkan kasasi.

Selain penyelesaian sengketa tersebut, para pihak dapat menyelesaikan sengketa melalui arbitrase atau alternatif penyelesaian sengketa. Penyelesaian sengketa melalui arbitrase atau alternatif penyelesaian sengketa dilaksanakan sesuai dengan ketentuan peraturan perundang-undangan yang berlaku yaitu UU No. 30 Tahun 1999. Dalam hal terjadi tuntutan pidana terhadap pelanggaran Paten atau Paten sederhana selain pembajakan, para pihak harus terlebih dahulu menyelesaikan melalui jalur mediasi. Ketentuan tersebut tidak diatur sebelum berlakunya UU Paten. Pencantuman "keharusan mediasi" yaitu negosiasi diantara para pihak yang bersengketa dengan bantuan pihak ketiga yang netral menguatkan fungsi hukum pidana sebagai "ultimum remedium", artinya hukum pidana dapat digunakan sebagai upaya terakhir apabila upaya lain tidak dapat dilakukan. Di sisi lain, penulis berpendapat bahwa sengketa terkait paten, pada dasarnya lebih dominan aspek keperdataan, karena itu jalur mediasi lebih tepat untuk dilakukan, kecuali "pembajakan" yang tidak layak untuk diselesaikan secara mediasi

\footnotetext{
22 Jabalnur, "Pelindungan Hak Paten Bagi Pengrajin Khas", Jurnal Holrev, Volume 1 Issue 2, 2017, hlm 287.
} 
karena perbuatan tersebut merupakan "degradasi moral”, sehingga pelaku perlu diberikan sanksi pidana.

Atas permintaan pihak yang dirugikan karena pelaksanaan Paten, Pengadilan Niaga dapat menerbitkan Surat Penetapan Sementara untuk mencegah masuknya barang yang diduga melanggar Paten dan/atau hak yang berkaitan dengan Paten; mengamankan dan mencegah penghilangan barang bukti oleh pelanggar; dan/atau c. menghentikan pelanggaran guna mencegah kerugian yang lebih besar. Penetapan sementara pengadilan merupakan mekanisme baru dalam paket UU KI, sebagai pelaksanaan dari Article 50 Trade Related Intelectual Property (TRIPs), yang dikenal dengan istilah "injunction". Penetapan sementara (provisional measures), secara substansi, diatur dalam Pasal 50 Perjanjian TRIPs yang mengharuskan para anggota untuk mencegah terjadinya suatu pelanggaran atas KI dan untuk menjaga bukti yang relevan sehubungan dengan pelanggaran yang digugat (Section 3: Provisional Measure, Article 50 (1), TRIPS Agreement). ${ }^{23}$ Penetapan sementara ${ }^{24}$ berbeda dengan "Provisional Decision" atau dikenal dengan Putusan Sela yaitu suatu putusan yang dimintakan setelah kasus utama disidangkan yang di atur dalam Pasal 180 HIR (Herziene Indonesich Reglemen)/Hukum Acara Perdata Indonesia. ${ }^{25}$

Tindakan hukum terhadap pelanggaran paten baik berupa gugatan dan penetapan sementara merupakan fungsi hukum sebagai kontrol sosial dan rekayasa sosial. Dari sisi kontrol sosial, inventor atau pemegang paten dapat melakukan tindakan hukum tersebut apabila mengetahui adanya pelanggaran haknya oleh pihak lain, sehingga pemegang paten atau inventor harus senantiasa mengawasi paten yang dimilikinya utuk memastikan bahwa tidak terjadi pelanggaran paten. Dari segi rekayasa sosial, pihak lain yang tidak berhak dan memahami sanksi perdata maupun pidana didalam UU Paten dapat mengurungkan niatnya untuk melakukan pelanggaran terhadap paten terdaftar. Sanksi merupakan reaksi terhadap kaidah yang dilanggar dapat berfungsi sebagai aspek preventif yaitu mencegah pihak lain yang tidak berhak untuk melakukan pelanggaran karena berdampak pada sanksi yang akan diterimanya, dan menjadi aspek represif dalam arti seseorang yang terlanjur melanggar paten pihak lain mendapat sanksi ganti rugi, denda, atau penjara.

Hukum sebagai kontrol sosial menetapkan tingkah laku manusia yang dapat didefinisikan sebagai sesuatu yang menyimpang terhadap aturan hukum paten, sehingga dapat dapat memberikan sanksi atau tindakan terhadap pelanggar. Hal ini berarti bahwa

\footnotetext{
${ }^{23}$ Inge Dwisvimiar Sariyah, "Kekuatan Hukum Penetapan Sementara Pengadilan (Injunction) Sebagai Bentuk Perlindungan Terhadap Pemilik Merek Dari Adanya Pelanggaran Merek", Jurnal Dinamika Hukum, Vol 14, 2014, hlm 63.

${ }^{24}$ Penetapan sementara berawal dari celebrated case (Anton Piller v. Manufacturing Processes) yang terjadi di Inggris pada tahun 1976. Penetapan sementara ini memungkinkan penggugat untuk menuntut akses ke tempat tergugat untuk mencari pelanggaran properti dan dokumen yang mengandung ancaman nyata bahwa bukti tersebut hilang jika aksi itu dimulai dengan cara biasa. Lihat Jeff Berryman, "Thirty Years After: Anton Piller orders and the Supreme and Federal Courts of Canada", Journal of International Commercial Law and Technology, Vol. 2 Issue 3, 2007, hlm 128. Lihat juga Inge Dwisvimiar Sariyah, op.cit, hlm 64. ${ }^{25}$ Suyud Margono, "Dampak Implementasi TRIPs Agreement terhadap prosedur upaya hukum HaKI di Indonesia”, Jurnal Supremasi Hukum, Vol. III No. 1, 2012, hlm 8.
} 
hukum mengarahkan agar masyarakat berbuat secara benar menurut aturan sehingga ketentraman terwujud. ${ }^{26}$ Sejalan dengan hal ini dalam upaya penegakan hukum terhadap pelanggaran, sebagaimana yang diungkapkan oleh Lawrence M. Friedman, hukum harus diartikan sebagai suatu isi hukum (content of law), tata laksana hukum (structure of law) dan budaya hukum (culture of law). Penegakan hukum tidak saja dilakukan melalui perundang-undangan (UU paten), tetapi memberdayakan aparat dan fasilitas hukum serta menciptakan budaya hukum masyarakat yang kondusif agar tidak melakukan pelanggaran paten. ${ }^{27}$ Hal ini selaras dengan pendapat Henny Nuraeny bahwa "to anticipate it required a legal effort in the prevention and protection.

Agar pelaksanaan perundang-undangan yang bertujuan untuk pembaharuan itu dapat berjalan sebagaimana mestinya, hendaknya perundang-undangan yang dibentuk itu sesuai dengan-inti pemikiran aliran sociological jurisprudence yaitu hukum yang baik hendaknya sesuai dengan hukum yang hidup (penulis: living law) di dalam masyarakat. Menurut Aliran sociological jurisprudence penerapan hukum tidak hanya dipahami sebagai upaya social control yang bersifat formal dalam menyelesaikan konflik, tetapi sekaligus mendesain penerapan hukum itu sebagai upaya social engineering, ${ }^{29}$ baik melalui perundang-undangan maupun putusan pengadilan. ${ }^{30}$ Kebijakan pemerintah untuk mengubah prilaku masyarakat sesuai dengan living law berkaitan dengan sistem pelindungan paten didasari pemikiran perlunya ada perubahan UU, yaitu dari UU Paten yang lama (Undang-Undang No 14 Tahun 2001) direvisi dengan Undang-Undang No 13 Tahun 2016. Beberapa point revisi yang bertujuan untuk melakukan perubahan sosial baik social control maupun social engineering sebagaimana tercantum Penjelasan Umum UU No. 13 Tahun 2016 tentang Paten.adalah:

1. Optimalisasi kehadiran Negara dalam Pelayanan Terbaik Pemerintah di bidang Kekayaan Intelektual;

2. Keberpihakan pada kepentingan Indonesia tanpa melanggar prinsip-prinsip Internasional;

3. Mewujudkan kemandirian ekonomi dengan menggerakkan sektor-sektor strategis ekonomi domestik dengan mendorong Invensi nasional di bidang teknologi untuk mewujudkan penguatan teknologi;

4. Membangun landasan Paten Nasional melalui pendekatan sistemik realisme hukum pragmatis (Pragmatic Legal Realism).

\footnotetext{
${ }^{26}$ Ashadi L Diab, "Peranan Hukum Sebagai Social Control, Social Engineering dan Social Welfare", Jurnal Al- 'Adl, Vol. 7 No. 2, 2014, hlm 58.

${ }^{27}$ Cecep Wiharma, "Penegakan Hukum legalistik Dalam Perspektif Sosiologis", Jurnal Hukum Mimbar Justitia Fakultas Hukum Universitas Suryakancana, Vol. 3 No. 2, 2017.

${ }^{28}$ Henny Nuraeny, "Trafficking of Migrant Workers in Indonesia: A Legal Enforcement and Economic Perspective of Prevention and Protection Effort European Research", Studies Journal, Volume XX Issue 4B, 2017, hlm 17.

${ }^{29}$ Marsudi Dedi Putra, "Kontribusi Aliran Sociological Jurisprudence Terhadap Pembangunan Sistem Hukum Indonesia”, Likhitaprajna Jurnal Ilmiah Fakultas Keguruan dan Ilmu Pendidikan, Volume. 16 Nomor 2, 2016, hlm 51.

${ }^{30}$ Ridwan, Hukum dan Perubahan Sosial, "Perdebatan Dua Kutub Antara Hukum Sebagai Social Control dan Hukum Sebagai Social Enginneering”, Jurisprudence, Vol. 6 No. 1, 2016, hlm 38.
} 
Pelayanan terbaik pemerintah dibidang kekayaan intelektual khususnya paten, merupakan social engineering agar masyarakat menyadari bahwa Negara menjalankan fungsi memajukan kesejahteraan umum sebagaimana tercantum dalam Pembukaan Undang-Undang Dasar 1945 Alinea IV, sehingga mendorong timbulnya kesadaran hukum masyarakat bahwa invensi teknologinya akan mendapat pelindungan hukum setelah memenuhi persyaratan yang ditentukan dalam UU Paten antara lain melakukan prosedur pendaftaran. Seringkali timbul stigma di masyarakat bahwa pendaftaran paten sulit dan memerlukan waktu yang lama tetapi dengan adanya optimalisasi pemerintah dalam pelayanan terbaik akan mengubah persepsi masyarakat bahwa pendaftaran paten penting bukan hanya untuk menjamin kepastian hukum berkaitan dengan bukti kepemilikan paten tetapi juga sebagai dasar bagi pemerintah untuk melakukan kebijakan dalam melindungi paten nasional. Namun kebijakan tersebut menunjukan keberpihakan terhadap kepentingan Indonesia tanpa melanggar prinsip-prinsip internasional, karena pada hakekatnya Undang-Undang No 13 Tahun 2016 mengimplementasikan ketentuan internasional dibidang Kekayaan Intelektual (TRIPs-WTO), sehingga UU Paten Indonesia pada hakekatnya mengharmonisasikan kedua kepentingan tersebut.

Fungsi hukum (paten) sebagai social engineering tercermin dari praktek penerapannya yang mewujudkan kemandirian ekonomi dengan menggerakkan sektorsektor strategis ekonomi domestik dengan mendorong Invensi nasional di bidang teknologi untuk mewujudkan penguatan teknologi dan membangun landasan Paten Nasional melalui pendekatan sistemik realisme hukum pragmatis (Pragmatic Legal Realism $)^{31}$. Inti pemikiran dari aliran pragmatic legal realism adalah Law as a tool of sosial engineering yang dikemukakan oleh Roscoe Pound ${ }^{32}$, yang merupakan inti pemikiran dari aliran pragmatic legal realism itu, oleh Mochtar Kusumaatmadja kemudian dikembangkan di Indonesia. Menurut pendapat Mochtar Kusumaatmadja, konsepsi hukum sebagai sarana pembaharuan masyarakat Indonesia lebih luas jangkauan dan ruang lingkupnya lebih menonjolnya perundang-undangan dalam proses pembaharuan hukum di Indonesia (meskipun yurisprudensi juga berperan) dan menolak sifat mekanisme dari konsepsi tersebut yang akan menghasilkan paham legisme yang berpandangan sempit "hukum adalah undang-undang". Sifat mekanisme itu nampak dengan digunakannya istilah "tool" oleh Roscoe Pound. ${ }^{33}$ Karena itu Mochtar Kusumaatmadja cenderung menggunakan istilah "sarana” daripada "alat". Disamping

\footnotetext{
31 Sudjana, "Pendekatan Sistemik Realisme Hukum Pragmatis (Pragmatic Legal Realism) Sebagai Landasan Paten Nasional Dalam Perspektif Pembangunan Teknologi Indonesia", Artikel Dalam Buku "Dinamika Hukum Dalam Pembangunan berkelanjutan; Kumpulan Karya Tulis Menghormati 80 tahun Prof Eddy Damian”, Bandung: PT Alumni, 2017, hlm 370-387.

32 Wahyu Nugroho, "Rekonstruksi Teori Hukum Pembangunan Kedalam Pembentukan Perundangundangan Lingkungan Hidup dan Sumber Daya Alam Pasca Reformasi Dalam Bangunan Negara Hukum", Jurnal Legislasi Indonesia, Vol. 14 No. 04, 2017, hlm 370.

${ }^{33}$ Nazaruddin Lathif, "Teori Hukum Sebagai Sarana / Alat Untuk Memperbaharui Atau Merekayasa Masyarakat”, Pakuan Law Review, Volume 3 Nomor 1, 2017, hlm 82.
} 
disesuaikan dengan situasi dan kondisi di Indonesia konsepsi tersebut dikaitkan pula dengan filsafat budaya dari Northrop dan policy oriented dari Laswell dan Mc Dougal.

Fungsi hukum (paten) sebagai social control tampak pada urgensi perubahan Undang-Undang No 14 Tahun 2001 menjadi Undang-Undang No 13 Tahun 2016 antara lain: pemberian lisensi-wajib (compulsory licensing) atas permintaan Negara berkembang (developing country) atau negara belum berkembang (least developed country $)^{34}$ yang membutuhkan produk farmasi yang diberi paten di Indonesia untuk keperluan pengobatan penyakit yang sifatnya endemi, dan produk farmasi tersebut dimungkinkan diproduksi di Indonesia, untuk diekspor ke negara tersebut. Sebaliknya pemberian lisensi-wajib untuk mengimpor pengadaan produk farmasi yang diberi paten di Indonesia, namun belum mungkin diproduksi di Indonesia untuk keperluan pengobatan penyakit yang sifatnya endemik, seperti Covid 19.

Lisensi wajib (compulsory licensing) paten merupakan salah satu pembatasan hak eksklusif (exclusive right), artinya pemberian hak tersebut bukan bersifat tanpa batas karena Negara boleh mengatur pengecualian secara terbatas, tetapi ada alasan yang sah sehingga tidak bertentangan dengan eksploitasi normal paten dan tidak merugikan kepentingan yang wajar dari Pemegang Paten, serta dengan tetap memperhitungkan kepentingan pihak ketiga. Lisensi wajib dalam hal ini dapat diberikan pada dua kategori pengguna yakni Pemerintah (atau badan Pemerintah atau pihak ketiga yang di beri kewenangan oleh negara) dan pihak ketiga pribadi lainnya). ${ }^{35}$ Berkaitan dengan Lisensi wajib, Undang-Undang No. 11 Tahun 2020 mengubah ketentuan Pasal 82 ayat (1) huruf a dalam UU Paten menjadi: "Paten tidak dilaksanakan di Indonesia sebagaimana dimaksud dalam Pasal 20 dalam jangka waktu 36 (tiga puluh enam) bulan setelah diberikan paten." Meskipun demikian, tidak terdapat perbedaan mendasar tentang lisensiwajib yang merupakan lisensi untuk melaksanakan paten yang diberikan berdasarkan Keputusan Menteri atas dasar permohonan dalam Undang-Undang No. 11 Tahun 2020 tentang Cipta Kerja.

\section{PENUTUP}

Fungsi hukum sebagai kontrol sosial terkait dengan obyek pelindungan, syarat dan cara pelindungan, dan jangka waktu pelindungan karena hukum (UU Paten) menetapkan persyaratan tertentu agar kreasi teknologi yang dihasilkan mendapat pelindungan pada kurun waktu tertentu dengan terlebih dahulu dilakukan pengumuman sebelum paten diberikan, sehingga apabila ada pihak lain (anggota masyarakat) yang mengetahui bahwa paten tersebut tidak memenuhi persyaratan dapat mengajukan keberatan atau pembatalan.

\footnotetext{
34 Samariadi, "Pelaksanaan Compulsory Licensing Paten Obat-Obatan Bidang Farmasi Di Indonesia Dikaitkan Dengan Doha Declaration on The TRIPS Agreement and Public Health", De Lega Lata, Volume I Nomor 2, 2016, hlm 459.

35 Tony Hanoraga dan Niken Prasetyawati, "Lisensi Wajib Paten Sebagai Salah Satu Wujud Pembatasan Hak Eksklusif Paten”, Sosial Humaniora, Vol. 8 No. 2, 2015, hlm 179.
} 
Pelindungan terhadap subyek paten merupakan fungsi hukum sebagai rekayasa sosial karena memotivasi atau mendorong masyarakat (inventor potensial) untuk menghasilkan kreasi teknologi agar dapat diberikan paten yang memiliki hak khusus, seperti hak ekonomi yang dapat meningkatkan taraf kehidupannya. Tindakan hukum yang dapat dilakukan oleh inventor atau pemegang paten terhadap pelanggaran paten baik secara perdata maupun pidana, berakibat pemegang paten senantiasa mengawasi hak paten yang dimilikinya. Di pihak lain, masyarakat yang memahami adanya sanksi apabila melanggar hak paten cenderung untuk mengurungkan niatnya. Hal ini berarti menyiratkan bahwa UU Paten memiliki fungsi hukum sebagai kontrol sosial sekaligus rekayasa sosial.

Untuk memahami syarat-syarat pemberian paten dan menghilangkan kesan pendaftaran paten terlalu prosedural serta meningkatkan kesadaran hukum masyarakat agar menghargai kreasi teknologi pihak lain yang dilindungi UU Paten, perlu dilakukan sosialisasi atau informasi secara berkesinambungan melalui media cetak atau elektronik dengan pemanfaatan sarana teknologi yang pada saat ini berkembang pesat agar dapat mendukung efektivitas kontrol sosial dan rekayasa sosial sebagaimana amanat UU Paten.

\section{DAFTAR PUSTAKA}

\section{Buku}

Burhan Ashshofa, Metode Penelitian Hukum, Jakarta: Penerbit Reineka Cipta, 2016.

Candra Irawan, Politik Hukum Hak Kekayaan Intelektual Indonesia: Kritik Terhadap WTO/TRIP's Agreement dan Upaya Membangun Hukum Kekayaan Intelektual Demi Kepentingan Nasional, Bandung: Mandar Maju, 2011.

Japan Patent Office, Industrial Property Rights-Standar, Textbook (General Information), Tokyo: JPO/JIII, 2007.

Muhammad Daud Ali, Hukum Islam Pengantar Ilmu Hukum dan Tata Hukum Islam di Indonesia, Jakarta: Raja Grafindo Persada. 2011.

Munir Fuady, Teori-Teori Besar (Grand Theory) Dalam Hukum, Jakarta: Kencana Prennamdeia Group, 2013.

Peter Mahmud Marzuki, Penelitian Hukum, Jakarta: Kencana Prenada Media Group, 2010 .

Rahmi Jened Parinduri Nasution, Interface Hukum Kekayaan Intelektual dan Hukum Persaingan (Penyalahgunaan HKI), Jakarta: Rajawali Press, 2013.

Ranti Fauza Mayana, Perlindungan Desain Industri di Indonesia dalam Era Perdagangan Bebas, Jakarta: Grasindo, 2004.

Soerjono Soekanto dan Sri Mamudji, Penelitian Hukum Normatif: Suatu Tinjauan Singkat, Jakarta: PT. Raja Grafindo Persada, 2015.

Tomi Suryo Utomo, Hak Kekayaan Intelektual (HKI) di Era Global, Yogyakarta: Graha Ilmu, 2010.

WIPO, Inventing the Future: An Introduction to Patens for Small and Medium-Sized Enterprises, Geneva, 2006. 
Dialogia luridica: Jurnal Hukum Bisnis dan Investasi

Volume 13 Nomor 1, November 2021

\section{Jurnal}

Ashadi L Diab, "Peranan Hukum Sebagai Social Control, Social Engineering dan Social Welfare”, Jurnal Al- 'Adl, Vol. 7 No. 2, 2014.

Atip Latipulhayat, "Khazanah: Roscoe Pound", Padjadjaran Jurnal Ilmu Hukum, Volume 1 No 2, 2014.

Berryman Jeff, "Thirty Years After: Anton Piller orders and the Supreme and Federal Courts of Canada", Journal of International Commercial Law and Technology, Vol. 2 Issue 3, 2007.

Cecep Wiharma, "Penegakan Hukum legalistik Dalam Perspektif Sosiologis", Jurnal Hukum Mimbar Justitia Fakultas Hukum Universitas Suryakancana, Vol. 3 No. 2, 2017.

Hanim Mafulah, "Pengecualian Perjanjian Yang Berkaitan Paten Dan Lisensinya Dalam Pengawasan Persaingan USAHA", SIGn Jurnal Hukum, Vol. 1 No. 2, 2020.

Henny Nuraeny, "Trafficking of Migrant Workers in Indonesia: A Legal Enforcement and Economic Perspective of Prevention and Protection Effort European Research", Studies Journal, Volume XX Issue 4B, 2017.

Indi Fandaya, "Pertanggungjawaban Pemegang Lisensi Wajib Menurut Undang-Undang Nomor 14 Tahun 2001 Tentang Paten”, USU Law Journal, Vol.5. No. 3, 2017.

Inge Dwisvimiar Sariyah, "Kekuatan Hukum Penetapan Sementara Pengadilan (Injunction) Sebagai Bentuk Perlindungan Terhadap Pemilik Merek Dari Adanya Pelanggaran Merek", Jurnal Dinamika Hukum, Vol 14, 2014.

Jabalnur, "Pelindungan Hak Paten Bagi Pengrajin Khas", Jurnal Holrev, Volume 1 Issue 2, 2017.

Marsudi Dedi Putra, "Kontribusi Aliran Sociological Jurisprudence Terhadap Pembangunan Sistem Hukum Indonesia", Likhitaprajna Jurnal Ilmiah Fakultas Keguruan dan Ilmu Pendidikan, Volume 16 Nomor 2, 2016.

Nazaruddin Lathif, "Teori Hukum Sebagai Sarana / Alat Untuk Memperbaharui Atau Merekayasa Masyarakat", Pakuan Law Review, Volume 3 Nomor 1, 2017.

Novianti. "Pelindungan Paten Melalui Patent Cooperation Treaty dan Regulations Under the Patent Cooperation Treaty", Jurnal Negara Hukum, Vol. 8 No. 2, 2017.

Ridwan, "Hukum dan Perubahan Sosial: Perdebatan Dua Kutub Antara Hukum Sebagai Social Control dan Hukum Sebagai Social Enginnering”, Jurisprudence, Vol. 6 No. $1,2016$.

Samariadi, "Pelaksanaan Compulsory Licensing Paten Obat-Obatan Bidang Farmasi Di Indonesia Dikaitkan Dengan Doha Declaration On The TRIPS Agreement and Public Health", De Lega Lata, Volume I Nomor 2, 2016.

Sudjana, "Pendekatan Sistemik Realisme Hukum Pragmatis (Pragmatic Legal Realism) Sebagai Landasan Paten Nasional Dalam Perspektif Pembangunan Teknologi Indonesia", Artikel Dalam Buku "Dinamika Hukum Dalam Pembangunan berkelanjutan; Kumpulan Karya Tulis Menghormati 80 tahun Prof Eddy Damian”, Bandung: PT Alumni, 2017. 
Dialogia luridica: Jurnal Hukum Bisnis dan Investasi

Volume 13 Nomor 1, November 2021

Suyud Margono, "Dampak Implementasi TRIPs Agreement terhadap prosedur upaya hukum HaKI di Indonesia”, Jurnal Supremasi Hukum, Vol. III No. 1, 2012.

Tony Hanoraga dan Niken Prasetyawati, "Lisensi Wajib Paten Sebagai Salah Satu Wujud Pembatasan Hak Eksklusif Paten”, Sosial Humaniora, Vol. 8 No. 2, 2015.

Wahyu Nugroho, "Rekonstruksi Teori Hukum Pembangunan Kedalam Pembentukan Perundang-undangan Lingkungan Hidup dan Sumber Daya Alam Pasca Reformasi Dalam Bangunan Negara Hukum”, Jurnal Legislasi Indonesia, Vol. 14 No. 04, 2017.

Winner Sitorus, "Kepentingan Umum Dalam Pelindungan Paten", Jurnal Yuridika, Volume 29 No 1, 2014.

Yoyon M Darusman, "Kedudukan Serta Pelindungan Hukum Bagi Pemegang Hak Paten Dalam Kerangka Hukum Nasional Indonesia dan Hukum Internasional”, Yustisia, Vol. 5 No. 1, 2016.

\section{Peraturan Perundang-undangan}

Undang-Undang Dasar 1945.

Herziene Indonesich Reglemen atau Hukum Acara Perdata Indonesia.

Undang-Undang Nomor 30 Tahun 1999 tentang Arbitrase dan Alternatif Penyelesaian Sengketa.

Undang-Undang Nomor 13 Tahun 2016 tentang Paten.

Undang-Undang Nomor 11 Tahun 2020 tentang Cipta karya.

\section{Pranalar Luar}

Arbitration Institute of the Stockholm Chamber of Commerce, https://sccinstitute.com/our-services/calculator/, diakses pada tanggal 25 Agustus 2020 pukul 20.00 WIB.

Dewi Iriani, Hukum Sebagai Alat Kontrol Sosial dan Sistem Supremasi Penegakan Hukum, http://repository.iainponorogo.ac.id/256/1/sebagai\%20kontrol.pdf, diakses pada tanggal 26 Oktober 2021 pukul 20.00 WIB.

http://badanbahasa.kemdikbud.go.id/lamanbahasa/content/apa-perbedaan-maknapelindungan-dan-pelindungan, diakses pada tanggal 15 Juni 2021 pukul 22 WIB.

Mieke Yustia Ayu Ratna Sari, Pembangunan Kekayaan Intelektual (KI) Berbasis Teknologi Informasi di Era Global, tersedia dalam https://media.neliti.com/, diakses pada tanggal 19 Maret 2021 pukul 21.00 WIB.

Paris Convention for the Protection of Industrial Property March 20, 1883, https://www.wipo.int/treaties/en/ip/paris/, diakses pada tanggal 17 Maret 2021 pukul 22.00 WIB.

Patent Cooperation Treaty 1970, https://www.wipo.int/pct/en/treaty/about.html, diakses pada tanggal 15 April 2021 pukul 19.00 WIB.

Wibowo T. Tunardy, Sociological Jurisprudence, https://www.jurnalhukum.com/sociological-jurisprudence/, diakses pada tanggal 23 September 2021 pukul 21.00 WIB. 